\title{
Production of Cookies Enriched With Spirulina platensis Biomass
}

\author{
Nilcimelly Rodrigues Donato \\ Federal University of Campina Grande, Center for Education and Health. Cuité, PB - Brazil \\ E-mail: mellydonato@gmail.com
}

Alexandre José de Melo Queiroz

Federal University of Campina Grande, Center of Science and Technology, Department of Agricultural Engineering Campina Grande, PB - Brazil

E-mail: alex@deag.ufcg.edu.br

\section{Rossana Maria Feitosa de Figueirêdo}

Federal University of Campina Grande, Center of Science and Technology, Department of Agricultural Engineering Campina Grande, PB - Brazil

E-mail: rossana@deag.ufcg.edu.br

\section{Regilane Marques Feitosa}

Federal Institute of Education, Science, and Technology of Alagoas, Campus Piranhas, Piranhas, AL, Brazil,

E-mail: regilanemarques@gmail.com

\section{Inacia dos Santos Moreira}

(Corresponding author) Federal University of Campina Grande Campina Grande, PB, Brazil Tel: 55-083 2101-1055 E-mail: inaciamoreira@gmail.com

José Franciraldo de Lima

Federal University of Campina Grande, Center of Science and Technology, Department of 
Agricultural Engineering Campina Grande, PB - Brazil

E-mail: josefranciraldo@gmail.com

Received: Oct. 8, 2019

doi:10.5296/jas.v7i4.15483
Accepted: Nov. 5, 2019

Published: Nov. 10, 2019

URL: https://doi.org/10.5296/jas.v7i4.15483

\begin{abstract}
Spirulina platensis is a cyanobacterium that can be consumed by humans, for its high contents of proteins and nutraceutical compounds. This study aimed to develop cookies mixed with $S$. platensis for nutritional enrichment purposes. The study conducted quality control analyses and elaborated formulations of cookies with different contents of S. platensis $(0,5,10$ and $15 \%)$, which were subjected to physical, chemical, microbiological and sensory analyses. In the cookies, the increase of S. platensis percentage led to increment in protein percentage, besides increments in minerals, compared with the cookie produced with only refined wheat flour. Cookies with $15 \%$ of S. platensis (F5) stood out regarding the percentages of protein and minerals, and were similar to the whole cookies with respect to the minerals; lipids and highest energetic value were observed in the standard cookies. Cookies mixed with $5 \%$ of S. platensis and standard cookies were preferred with the same score, indicating a possible acceptance in the market.
\end{abstract}

Keywords: microalgae, physicochemical characterization, sensory analysis

\title{
1. Introduction
}

Currently, there is a large-scale cultivation of cyanobacteria, which represents an economically viable source of proteins, capable of meeting the requirements of human diet and also allowing other products for human consumption to be obtained (Zepka et al., 2010). The biotechnology of microalgae has been developed for different commercial applications, including the development of nutraceutical supplements, and some species produce bioactive compounds, such as antioxidants, anti-inflammatory drugs, hypolipidemic agents, antibiotics and toxins (Banji et al., 2013; Garcia-Casal et al., 2009; Mazokopakis et al., 2013; Mazokopakis et al., 2014; Vázquez-Velasco et al., 2014).

Spirulina stands out for having a diversified biochemical composition and is used in food technology processes due to its high contents of proteins, essential amino acids, vitamins (especially B12), mineral salts, besides pigments (carotenoids, phycocyanins and chlorophylls), polyunsaturated fatty acids, including Omega-3 fatty acids and other biologically active compounds (Colla et al., 2007; Mazokopakis et al., 2008; Oliveira et al., 2010). Among micronutrients, iron, manganese, zinc and copper stand out (Moreira et al., 2013). It contains ten times more $\beta$-carotene than any other food, including carrots (Mohammed and Mohd, 2011). 
The interest in algae biomass production has become intense in the last six decades, due to the scarcity of food worldwide (Tharwat and Alturki, 2014). There are at least two reasons to think about the role of Spirulina biomass in human diet: the reproduction speed of the microorganisms and the level of control that can be exerted over their growth conditions (Sassano et al., 2010; Kim et al., 2013).

Madkour, Kamil and Nasr (2012) observed that the biomass of Spirulina cultivated under different conditions had protein contents of $37.79-52.95 \%$, carbohydrate contents of $13.20-24.5 \%$ and lipid contents of 5.64-15.39\%. Among the vitamins, cyanocobalamin is one of the most abundant in Spirulina (2 to 6 times richer than raw bovine liver), and it has 70, 50 and $12 \%$ of vitamins B1, B2 and B3, respectively, besides being a good source of tocopherol (vitamin E) (Mishra; Singh and Prasad, 2014).

Given the constant search for better life quality and, consequently, better diet, enriched foods emerge as an alternative to facilitate the consumption of healthy products with practicality, without the need for previous preparation (Moura et al., 2014). Among the products that can be enriched and mixed with Spirulina, an outstanding option is the cookie, which is a popular food due to its practicality, since it can be easily transported and has long shelf life. Batool et al. (2013) observed protein enrichment in cookies with the addition of Nigella sativa. For Mohsen et al. (2009), protein enrichment of cookies occurred through the replacement of wheat flour with isolated soy protein. The enrichment of food products can be performed with different nutrients (Moura et al., 2014). The use of cyanobacteria as a non-conventional source of foods and protein seems to be promising (Mishra, Singh and Prasad, 2014).

The nutraceutical characteristics of Spirulina cause it to be indicated for various profiles of consumers, but its low palatability is an obstacle for consumption. Given the above, its incorporation to other foods becomes convenient, allowing it to reach most of the potential users with a healthy, nutritious and economically accessible product. The aim of this work was to investigate the addition of $S$. platensis biomass to cookies in order to evaluate their antioxidant potential, nutritional enrichment and their technological, microbiological and sensory properties.

\section{Material and Methods}

The microorganism Spirulina platensis was cultivated in open photobioreactor. The utilized strain was FT001, cultivated in masonry tanks, aerated with Aeromack aerator, model CRE-01, with continuous flow of $1.4 \mathrm{~m}^{3} / \mathrm{min}$, natural photoperiod, fully using daytime insolation, and mean temperature of $31^{\circ} \mathrm{C}$. After harvest, the fresh S. platensis was washed in distilled water, homogenized in domestic mixer for 20 seconds and then filtered through a $60-\mu \mathrm{m}$ mesh. Then, the material was arranged on trays in an approximately 1-cm-thick layer and frozen in a commercial freezer at $-18{ }^{\circ} \mathrm{C}$ for 14 hours. After this time, the trays were immediately transferred to lyophilizer (Terroni ${ }^{\circledR}$ ) and dehydrated at $-49{ }^{\circ} \mathrm{C}$ for 7 hours, at a pressure of $0.02955 \mathrm{mmHg}$. After drying, the samples were ground/homogenized in domestic processor for 1 minute, to obtain the pulverized product.

Five different cookie formulations were made, three of which were incorporated with 
lyophilized biomass of $S$. platensis (BS), following a methodology adapted from the method 10-50 D of the American Association of Cereal Chemists (AACC, 2000), namely: F1 - with $0 \%$ of BS (control 1), produced with refined wheat flour (RWF); F2 - with $0 \%$ of BS (control 2), produced with whole wheat flour (WWF); F3 - with 5\% of BS and 95\% of RWF; F4 with $10 \%$ of BS and $90 \%$ of RWF; F5 - with $15 \%$ of BS and $85 \%$ of RWF, besides the other ingredients, totaling 5 samples, which were analyzed in triplicate. The cookie formulations are presented in Table 1.

Table 1. Formulations of the five types of cookies

\begin{tabular}{lccccc}
\hline Ingredients/ Formulations & F1 & F2 & F3 & F4 & F5 \\
Refined wheat flour (RWF) & 100 & --- & 95 & 90 & 85 \\
Whole wheat flour (WWF) & --- & 100 & --- & --- & --- \\
Biomass of S. platensis (BS) & --- & --- & 5 & 10 & 15 \\
\hline Soybean oil & 15 & 15 & 15 & 15 & 15 \\
Lecithin & 3.0 & 3.0 & 3.0 & 3.0 & 3.0 \\
Egg & 60 & 60 & 60 & 60 & 60 \\
Salt & 1 & 1 & 1 & 1 & 1 \\
Sodium bicarbonate & 1.0 & 1.0 & 1.0 & 1.0 & 1.0 \\
Sugar & 30 & 30 & 30 & 30 & 30 \\
Water & 15 & 15 & 15 & 15 & 15 \\
Vanilla essence & 2 & 2 & 2 & 2 & 2 \\
\hline
\end{tabular}

Obs.: Quantities in percentage $(\mathrm{m} / \mathrm{m})$ based on the total amount of wheat flour

A mixture of oil, sugar, eggs, water, vanilla essence and lecithin was used to prepare a cream, which was then mixed with wheat flour, salt and sodium bicarbonate, dissolved in water and homogenized for 3-5 min. The dough was left to rest for $20 \mathrm{~min}$ and the cookies were shaped using roller mold with $3-\mathrm{cm}$-diameter circles and baked at temperature of $210^{\circ} \mathrm{C}$, for $15 \mathrm{~min}$. Then, the cookies were cooled at room temperature, $25 \pm 3{ }^{\circ} \mathrm{C}$, and stored in polyethylene packages.

After processing, the cookie formulations were subjected to analyses of instrumental color and texture, in triplicate. Color was analyzed in a portable spectrophotometer, Hunter Lab Mini Scan XE Plus, model 4500 L, to obtain the readings of the parameters L*, which defines lightness $\left(\mathrm{L}^{*}=0-\right.$ black and $\mathrm{L}^{*}=100-$ white $)$ and $\mathrm{a}^{*}$ and $\mathrm{b}^{*}$, which are responsible for 


\section{Macrothink}

chromaticity $\left(+a^{*}=\right.$ red and $-a^{*}=$ green; $+b^{*}=$ yellow and $-b^{*}=$ blue $)$. Texture attributes were analyzed based on tests of fiber resistance and compression of the formulated cookies. The tests were conducted in texture meter, TA.XT plus, with 10 replicates for each attribute.

The cookies and lyophilized biomass were characterized through the parameters moisture content, fixed mineral residue (ashes), lipids, proteins and crude fiber; total carbohydrates were determined by difference between the sum of moisture contents, ashes, lipids and proteins, and the total (IAL, 2008). Chlorophyll a was quantified in spectrophotometer, according to Arnon (1949). The caloric value was calculated based on the contents of the protein fraction, lipid fraction and carbohydrates, using the specific coefficients that consider combustion heats of 4.0, 9.0 and $4.0 \mathrm{kcal}$, respectively, according to Brasil et al. (2003). The ascorbic acid content was determined according to AOAC (1997), modified by Benassi and Antunes (1998). Minerals were quantified in Dispersive Energy X-Ray Fluorescence Spectrometer (Shimadzu EDX-720 (EDX)). Microbiological analyses of the cookie samples were carried out according to the methodology of Vanderzant and Splittstoesser (1992).

The five cookie formulations were subjected to test of acceptance, evaluating the following attributes: appearance, color, aroma, taste, texture and overall assessment, using a 9-point structured hedonic scale with scores from 1 (dislike extremely) to 9 (like extremely). The purchase intention test used a 5-point structured scale, in which the judges attributed scores from 1 (least preferred product) to 5 (most preferred product). The formulations were also compared regarding the relative preference, with scores ranging from 4 (most preferred sample) to 1 (least preferred sample).

This project was approved by the Ethics and Research Committee (SISNEP), with the CAAE $\mathrm{n}^{\circ}: 04781512.6 .0000 .5182$.

\subsection{Statistical Analysis}

The mean values of sensory acceptance test of the cookies were compared by Tukey test at 0.05 probability level, using the program ASSISTAT version 7.7 for Windows. The ranking test used the table of Newell \& MacFarlane (Faria and Yotsuyanagi, 2002).

\section{Results and Discussion}

\subsection{Chemical Composition}

Table 2 shows the results found for the characterization of the lyophilized biomass of $S$. platensis. 
Table 2. Mean values of chemical and physicochemical parameters of lyophilized S. platensis

Parameter

Moisture content (\%)

Ash (\%)

Proteins (\%)

Lipids (\%)

Crude fiber (\%)

Ascorbic acid (mg/100 g)

Chlorophyll (mg/g)

\section{S. platensis}

$11.99 \pm 0.04$

$8.00 \pm 0.04$

$58.62 \pm 0.38$

$11.46 \pm 0.05$

$2.02 \pm 0.06$

$44.84 \pm 0.64$

$9.48 \pm 0.31$

The moisture content $(11.99 \%)$ of the lyophilized S. platensis is close to those reported by Alvarenga et al. (2011), 11.92\%, and by Dotto et al. (2013), 9.7\%. Lower moisture contents were observed by Tharwat and Alturki (2014), 7\%, and by Lemes et al. (2012), 5.49 and $5.72 \%$.

One of the most remarkable characteristics, which highlights $S$. platensis as functional food, is its high protein content, so this alga has been indicated by a range of studies emphasizing this nutrient of high cost and essentiality for human development. Protein percentages of $58.20 \%$ (Alvarenga et al., 2011) and 59.65\% (Donato et al., 2010) are close to the result found in the present study, 58.62\%. Tharwat and Alturki (2014) and Dotto et al. (2013) reported protein contents of 61 and $67 \%$, respectively. Variations in the contents are attributed to cultivation characteristics, which depend on, among other factors, season of the year, temperature, lightness and rainfall (Kim et al., 2013).

Lipid contents of 7, 6 and 3.4\% were found by Dotto et al. (2013), Tharwat and Alturki (2014) and Oliveira et al. (2010), respectively. These values are lower than that found in the present study (11.46\%). For Oliveira et al. (2010), the lipids content is a relevant factor of this microalga, which contains in its composition a variety of polyunsaturated fatty acids, especially $\gamma$-linolenic acid.

\subsection{Cookies Sensory Analysis}

Table 3 shows mean values of the instrumental color parameters of the cookies: lightness $\left(\mathrm{L}^{*}\right)$, redness $\left(+\mathrm{a}^{*}\right)$, greenness $\left(-\mathrm{a}^{*}\right)$ and yellowness $\left(+\mathrm{b}^{*}\right)$.

Lightness $\left(\mathrm{L}^{*}\right)$ decreased on both top and bottom surfaces of the cookies, with the increase in S. platensis content, i.e., the cookies exhibited darkening when wheat flour was replaced with S. platensis. All cookie samples with S. platensis differed significantly $(\mathrm{p}<0.05)$, and the 
sample F5 B showed the lowest value of $\mathrm{L}^{*}$ (28.08), while the sample F2 T showed the highest $\mathrm{L}^{*}$ (41.74).

Table 3. Mean values of color parameters of the cookies: lightness $\left(\mathrm{L}^{*}\right)$, redness $\left(+\mathrm{a}^{*}\right)$, greenness $\left(-\mathrm{a}^{*}\right)$ and yellowness $\left(+\mathrm{b}^{*}\right)$

\begin{tabular}{cccc}
\hline Sample & $\mathbf{L}^{*}$ & $\mathbf{a}^{*}$ & $+\mathbf{b}^{*}$ \\
\hline F1 T & $34.81 \mathrm{bcd}$ & $54.16 \mathrm{a}$ & $13.50 \mathrm{bc}$ \\
F1 B & $29.40 \mathrm{de}$ & $41.53 \mathrm{~b}$ & $15.88 \mathrm{~b}$ \\
F2 T & $41.74 \mathrm{a}$ & $12.54 \mathrm{c}$ & $25.12 \mathrm{a}$ \\
F2 B & $36.97 \mathrm{ab}$ & $13.06 \mathrm{c}$ & $26.93 \mathrm{a}$ \\
F3 T & $36.03 \mathrm{abc}$ & $-0.74 \mathrm{ef}$ & $17.58 \mathrm{~b}$ \\
F3 B & $30.68 \mathrm{bcde}$ & $4.13 \mathrm{~d}$ & $23.31 \mathrm{a}$ \\
F4 T & $30.03 \mathrm{cde}$ & $-0.79 \mathrm{ef}$ & $12.92 \mathrm{bc}$ \\
F4 B & $29.63 \mathrm{cde}$ & $7.05 \mathrm{~d}$ & $16.40 \mathrm{~b}$ \\
F5 T & $28.74 \mathrm{de}$ & $-2.22 \mathrm{f}$ & $9.17 \mathrm{c}$ \\
F5 B & $28.08 \mathrm{e}$ & $2.90 \mathrm{de}$ & $14.46 \mathrm{~b}$ \\
\hline
\end{tabular}

F1 - cookies without addition of S. platensis, produced with refined wheat flour; F2 cookies without addition of S. platensis, produced with whole wheat flour; F3 - cookies with $5 \%$ of S. platensis; F4 - cookies with $10 \%$ of S. platensis; F5 - cookies with $15 \%$ of S. platensis; T - Top surface; B - Bottom surface. Means followed by the same letter in the columns do not differ statistically by Tukey test at 0.05 probability level

The replacement of wheat flour with S. platensis allowed the change in the intensity of red to green, for all formulated cookies. It is interesting to point out that this alteration was observed only on the top surface of the cookies; redness remained constant on the bottom surface. Yellowness was higher only for cookies made with whole wheat flour, and a constant behavior was observed for the others. Rodrigues, Caliari and Asquieri (2011), evaluating the replacement of cassava starch with dehydrated cassava meal, observed an increment in red and yellow colors, justifying this increment by the Maillard reaction in the materials, which showed relatively high contents of carbohydrates.

Color characteristics depend on physical and chemical features of the product, such as 
content of sugars, content of amino acids, water activity, $\mathrm{pH}$ etc., and on the conditions of baking, temperature, air speed, relative humidity, and heat and mass transfer coefficient (Chevallier et al., 2002).

Table 4 shows the values of resistance to compression, cut and penetration of the cookies relative to the five formulations. Physical characteristics like these are used to define the softness of a product, which in turn has influence on acceptability. A soft product exhibits slight resistance to the physical property of deformation; a firm product can be described as moderately resistant to this property, while hard describes a product with substantial resistance to deformation.

The formulation F3 exhibited the highest physical resistance, since it had highest values ( $p$ $<0.05$ ) for the three characteristics: compression, cut and penetration. Thus, cookies with F3 formulation (with $5 \%$ of $S$. platensis biomass) showed greater hardness compared with the others, since they required more force for compression, cut and penetration. In contrast, the F2 formulation, made with $100 \%$ of whole wheat flour, showed lower values for compression and penetration, followed by F5, which had the lowest values for cut. Marcílio et al. (2005), aiming to determine physical characteristics in cookies with amaranth flour, concluded that whole flour promotes a crumbly aspect in the cookies and demonstrated that hardness depends on two variables: fat content and bran content, provided by the whole flour.

Table 4. Results of the texture analyses for the five cookie formulations

\begin{tabular}{lccccc}
\hline \multirow{2}{*}{ Analyses } & \multicolumn{5}{c}{ Formulations } \\
\cline { 2 - 6 } & F1 & F2 & F3 & F4 & F5 \\
\hline Compression (N) & $400.05 \mathrm{ab}$ & $213.42 \mathrm{c}$ & $476.61 \mathrm{a}$ & $330.88 \mathrm{abc}$ & $259.60 \mathrm{bc}$ \\
Cut (N) & $84.12 \mathrm{a}$ & $47.64 \mathrm{~b}$ & $96.37 \mathrm{a}$ & $45.316 \mathrm{~b}$ & $41.32 \mathrm{~b}$ \\
Penetration (N) & $19.34 \mathrm{~b}$ & $9.30 \mathrm{c}$ & $27.62 \mathrm{a}$ & $9.83 \mathrm{c}$ & $10.31 \mathrm{c}$ \\
\hline
\end{tabular}

F1 - cookies without addition of S. platensis, produced with refined wheat flour; F2 cookies without addition of $S$. platensis, produced with whole wheat flour; F3 - cookies with $5 \%$ of S. platensis; F4 - cookies with $10 \%$ of S. platensis; F5 - cookies with $15 \%$ of S. platensis; Means followed by the same letters in the row do not differ statistically by Tukey test at 0.05 probability level

According to Rosell, Rojas and Barber (2001), the differences in water absorption are mainly caused by the large number of hydroxyl groups, which are present in the structure of the fiber and allow the interaction of more water in the hydrogen bonds. Thus, the incorporation of fibers in products increases the water binding capacity, affecting texture characteristics of dough samples, as evidenced in the results for the formulation F2 in the present study.

There was a statistical reduction in the set of texture characteristics with the increment in the $S$. platensis powder percentage, indicating that it somewhat influenced the increment of softness of the samples. Opposite results were reported by Simas et al. (2009), who observed 


\section{Macrothink}

Journal of Agricultural Studies

ISSN 2166-0379

2019, Vol. 7, No. 4

that the increase in the percentage of king palm in the cookies led to increase of hardness and fracture strength.

Table 5 shows the mean values of the physicochemical composition, as well as minerals, of the cookies formulated with refined and whole flours without addition of S. platensis, and of the three cookies mixed with $S$. platensis in different percentages. According to the quantification of the moisture contents, it was observed that the cookies did not follow a trend with the increase of $S$. platensis and reduction of flour, and the lowest content was found in the formulation F3 (8.38\%). Morais, Miranda and Costa (2009), studying the moisture content of chocolate cookies enriched with $S$. platensis (Sp) in amounts ranging from 0 (control) to $5.0 \%$ (dry basis), reported stability of the moisture content, equal to $7.5 \%$, which is close to that found in the present study. This possible variation can be justified by the position of the cookies in the oven, because they were subjected to the same temperature and baking time. 
Table 5. Mean values of physicochemical parameters and mineral elements (mg/100 g) in the cookies with S. platensis in different formulations

\begin{tabular}{|c|c|c|c|c|c|}
\hline \multirow{2}{*}{ Variable (\%) } & \multicolumn{5}{|c|}{ Formulations } \\
\hline & F1 & $\mathbf{F} 2$ & $\mathbf{F 3}$ & $\mathbf{F 4}$ & F5 \\
\hline Moisture content & $12.43 \pm 0.08^{\mathrm{c}}$ & $15.07 \pm 0.04^{\mathrm{b}}$ & $8.38 \pm 0.24^{\mathrm{d}}$ & $16.37 \pm 0.28^{\mathrm{a}}$ & $14.45 \pm 0.21^{\mathrm{b}}$ \\
\hline $\operatorname{Ash}(\%)$ & $0.82 \pm 0.22^{\mathrm{b}}$ & $1.68 \pm 0.19^{\mathrm{a}}$ & $1.03 \pm 0.02^{\mathrm{ab}}$ & $0.97 \pm 0.27^{\mathrm{b}}$ & $1.44 \pm 0.06^{\mathrm{ab}}$ \\
\hline Proteins (\%) & $11.42 \pm 0.04^{\mathrm{d}}$ & $12.71 \pm 0.16^{\mathrm{c}}$ & $12.87 \pm 0.24^{\mathrm{bc}}$ & $13.04 \pm 0.34^{\mathrm{bc}}$ & $15.30 \pm 0.16^{\mathrm{a}}$ \\
\hline Lipids (\%) & $\begin{array}{c}14.39 \\
\pm 0.05^{\mathrm{ab}}\end{array}$ & $14.21 \pm 0.09^{\mathrm{b}}$ & $14.81 \pm 0.17^{\mathrm{ab}}$ & $14.92 \pm 0.19^{\mathrm{a}}$ & $14.92 \pm 0.27^{\mathrm{a}}$ \\
\hline Crude fiber (\%) & $2.72 \pm 0.80^{\mathrm{a}}$ & $3.58 \pm 0.30^{\mathrm{a}}$ & $3.96 \pm 0.96^{\mathrm{a}}$ & $2.25 \pm 0.86^{\mathrm{a}}$ & $3.70 \pm 0.76^{\mathrm{a}}$ \\
\hline Carbohydrates (\%) & $58.22 \mathrm{~b}$ & $52.75 \mathrm{~cd}$ & $58.95 \mathrm{a}$ & $52.64 \mathrm{de}$ & $50.19 \mathrm{e}$ \\
\hline Caloric value (Kcal/100 g) & $408.07 \mathrm{~b}$ & $389.73 \mathrm{c}$ & 420.57 a & $397.00 \mathrm{c}$ & $396.24 \mathrm{c}$ \\
\hline $\mathrm{K}(\mathrm{mg} / 100 \mathrm{~g})$ & 260.0 & 710.0 & 380.0 & 320.0 & 650.0 \\
\hline $\mathrm{Ca}(\mathrm{mg} / 100 \mathrm{~g})$ & 100.0 & 200.0 & 120.0 & 90.0 & 160.0 \\
\hline $\mathrm{S}(\mathrm{mg} / 100 \mathrm{~g})$ & 250.0 & 390.0 & 290.0 & 200.0 & 330.0 \\
\hline $\mathrm{P}(\mathrm{mg} / 100 \mathrm{~g})$ & 100.0 & 180.0 & 110.0 & 80.0 & 140.0 \\
\hline $\mathrm{Fe}(\mathrm{mg} / 100 \mathrm{~g})$ & 30.0 & 40.0 & 30.0 & 30.0 & 60.0 \\
\hline $\mathrm{Si}(\mathrm{mg} / 100 \mathrm{~g})$ & 70.0 & 110.0 & 90.0 & 60.0 & 110.0 \\
\hline $\mathrm{Mn}(\mathrm{mg} / 100 \mathrm{~g})$ & - & 20.0 & - & - & - \\
\hline $\mathrm{Cu}(\mathrm{mg} / 100 \mathrm{~g})$ & 10.0 & 10.0 & 10.0 & 10.0 & - \\
\hline $\mathrm{Ag}(\mathrm{mg} / 100 \mathrm{~g})$ & 20.0 & - & - & - & - \\
\hline
\end{tabular}

F1 - cookies without addition of S. platensis, produced with refined wheat flour; F2 - cookies without addition of S. platensis, produced with whole wheat flour; F3 - cookies with 5\% of S. platensis; F4 - cookies with 10\% of S. platensis; F5 - cookies with $15 \%$ of S. platensis; Means followed by the same letters in the row do not differ statistically by Tukey test at 0.05 probability level

In studies on cookies conducted by Fasolin et al. (2007) using unripe banana meal, and Simas 
et al. (2009) with king palm flour, all results found for fixed mineral residue were between 1 and $2 \%$, which are close to those of the present research. In addition, there was an increase in fixed mineral residue with the increment of $S$. platensis in the formulations, positively influencing the quality of the cookies.

The replacement of wheat flour with S. platensis, in food products, even in small proportions, promotes an increment in the protein content.

The Brazilian Society for Food and Nutrition (SBAN) describes in the Resolution RDC $\mathbf{n}^{\mathbf{o}}$ 269, from September 22, 2005, of ANVISA (Brasil, 2005), the average daily requirements of nutrients (Recommended Daily Intake - RDI) for the Brazilian population. According to the established RDI percentages, a portion $(100 \mathrm{~g})$ of the cookies with addition of $15 \%$ of $S$. platensis, developed in the present research, provides $45 \%$ of the RDI of proteins for a 7-10 year-old child, and $30.60 \%$ of the daily requirements of an adult, while cookies without $S$. platensis (F1) provide $33.58 \%$ and $22.84 \%$, respectively. Based on this result, the cookies with $15 \%$ of S. platensis, according to the legislation (Brasil, 1998) can be considered as of "high content" or "rich" in proteins and also called enriched or fortified, for containing at least $30 \%$ of the RDI of protein.

The comparison between protein contents in the different cookie formulations and the RDIs for different age groups of the Brazilian population is presented in Table 6.

Table 6. Protein percentage in the different cookie formulations based on the RDI for each age group

\begin{tabular}{ccccccc}
\hline Age group & RDI* $(\mathbf{g})$ & $\mathbf{F 1}(\boldsymbol{\%})$ & $\mathbf{F 2}(\boldsymbol{\%})$ & $\mathbf{F 3}(\boldsymbol{\%})$ & $\mathbf{F 4}(\boldsymbol{\%})$ & $\mathbf{F 5}(\boldsymbol{\%})$ \\
\hline 1-3 years & 13 & 87.84 & 97.77 & 99.00 & 100.31 & 117.69 \\
4-6 years & 19 & 60.10 & 66.89 & 67.74 & 68.63 & 80.53 \\
7-10 years & 34 & 33.58 & 37.85 & 37.85 & 38.35 & 45.00 \\
Adult & 50 & 22.84 & 25.42 & 25.74 & 26.08 & 30.60 \\
$\begin{array}{c}\text { Pregnant and } \\
\text { lactating women }\end{array}$ & 71 & 16.08 & 17.90 & 18.13 & 18.37 & 21.55 \\
\hline
\end{tabular}

RDI - Recommended Daily Intake; F1 - cookies without addition of S. platensis, produced with refined wheat flour; F2 - cookies without addition of S. platensis, produced with whole wheat flour; F3 - cookies with 5\% of S. platensis; F4 - cookies with $10 \%$ of S. platensis; F5 cookies with $15 \%$ of S. platensis *Source: Brasil (2005)

The nutritional importance of the cookies supplemented with $S$. platensis can be noted in the comparison of protein content with other studies that use other sources of enrichment of this 
nutrient, such as Guilherme and Jokl (2005), who found the highest protein content $(11.74 \%)$ in a study with cookies using corn flour of better protein quality. Larosa et al. (2009), who worked with cookies containing $40 \%$ of "okara" flour (residue from soybean "milk" production), obtained $20.84 \%$ of protein.

Regarding the lipids, lower values were reported by Hoffmann and Kruger (2011), for cookies enriched with $8 \%$ of bovine liver (7.65\%), and Larosa et al. (2009), for cookies mixed with "okara" flour (9.16\%). Higher values were reported by Morais, Miranda and Costa (2009) in chocolate cookies supplemented with S. platensis (18.6\%), by Vieira et al. (2008), working with heart of palm residue (19.61\%), and by Mohsen et al. (2009), in cookies enriched with isolated soy protein $(19.42 \%)$.

For fiber content, the average value represented $3.24 \%$ of the centesimal composition of the cookies. Similar results were observed by Guilherme and Jokl (2005), who found a mean value of 3.06\% in cookies using corn flour; by Simas et al. (2009), who quantified $3.41 \%$ of fibers in gluten-free cookies with addition of $10 \%$ of king palm flour; and by Vieira et al. (2008), who found $3.89 \%$ of fibers in cookies with addition of king palm flour.

It can be noted that the increment in $S$. platensis biomass percentage in the cookie formulations contributes to the increase in the percentage of nutrients in the product, so it can be indicated as an interesting source of minerals and trace elements.

The recommended intake of phosphorus for an adult is $700 \mathrm{mg} / \mathrm{day}$. According to the quantification in the present study for the formulation F5, $100 \mathrm{~g}$ of cookies contain $20 \%$ of the daily requirements of this mineral for an adult. Calcium contents in the cookies enriched with S. platensis ranged from 90 to $160 \mathrm{mg} / 100 \mathrm{~g}$.

The potassium content in the formulation F5 was close to those of cookies mixed with 2 to $8 \%$ of cassava meal, analyzed by Rodrigues, Caliari and Asquieri (2011), who quantified these minerals with values from 780.00 to $793.33 \mathrm{mg} / 100 \mathrm{~g}$.

Another important macromineral, due to its participation in various organic chemical reactions and in most tissues, is sulfur, whose RDI has not been established. Its highest content was found in the formulation F2 $(390 \mathrm{mg} / 100 \mathrm{~g})$ followed by the formulation F5 (330 $\mathrm{mg} / 100 \mathrm{~g}$ ). These values are higher than those reported by Rodrigues, Caliari and Asquieri (2011) for this mineral in cookies with cassava meal, which ranged from 183 to $209 \mathrm{mg} / 100 \mathrm{~g}$ of cookie.

The microbiological evaluation (Table 7) indicated that the product is safe, within the limits defined by the legislation, according to $\operatorname{RDC~}^{\circ} 12$, of 2001 . 


\subsection{Microbiological Parameters}

Table 7. Mean values of the microbiological analyses conducted in different formulations of cookies

\section{Formulations}

\begin{tabular}{|c|c|c|c|c|c|c|}
\hline \multirow{2}{*}{ Determination } & & & & & & \multirow[b]{2}{*}{$\begin{array}{l}\text { RDC } \\
12 / 2001\end{array}$} \\
\hline & F1 & F2 & F3 & $\mathbf{F 4}$ & F5 & \\
\hline Coliforms at $35^{\circ} \mathrm{C} \mathrm{MPN}$ & $<3$ & $<3$ & $<3$ & $<3$ & $<3$ & - \\
\hline Coliforms at $45^{\circ} \mathrm{C} \mathrm{MPN}$ & $<3$ & $<3$ & $<3$ & $<3$ & $<3$ & 10 \\
\hline Mesophiles (CFU/g) & $1.8 \times 10^{2}$ & $1.8 \times 10^{2}$ & $1.1 \times 10^{1}$ & $9 \times 10^{0}$ & $9 \times 10^{0}$ & - \\
\hline Anaerobic (CFU/g) & $2 \times 10^{2}$ & $2.2 \times 10^{2}$ & $1.7 \times 10^{2}$ & $1.2 \times 10^{2}$ & $1.5 \times 10^{2}$ & - \\
\hline $\begin{array}{l}\text { Positive Coagulase } \\
\text { Staphylococci (CFU/g) }\end{array}$ & $<1$ & $<1$ & $<1$ & $<1$ & $<1$ & $5 \times 10^{2}$ \\
\hline $\begin{array}{l}\text { Molds and Yeasts } \\
(\mathrm{CFU} / \mathrm{g})\end{array}$ & $2 \times 10^{1}$ & $1 \times 10^{1}$ & $1 \times 10^{1}$ & $<1 \times 10^{2}$ & $<1 \times 10^{2}$ & - \\
\hline Salmonella sp./25 g & Absence & Absence & Absence & Absence & Absence & Absence \\
\hline
\end{tabular}

F1 - cookies without addition of $S$. platensis, produced with refined wheat flour; F2 - cookies without addition of $S$. platensis, produced with whole wheat flour; F3 - cookies with 5\% of $S$. platensis; F4 - cookies with $10 \%$ of S. platensis; F5 - cookies with $15 \%$ of S. platensis

Table 8 shows the mean values of the sensory acceptance and purchase intention tests, conducted with cookies made using refined wheat flour (common) and whole wheat flour, in analyses performed to verify if there is difference between their attributes.

For the characteristics of appearance, aroma and texture, there was no statistical difference ( $\mathrm{p}$ $<0.05$ ), but for the attributes color and taste there was statistical difference in favor of the cookies made with refined wheat flour, which obtained higher scores. The evaluated samples of cookies had good acceptance, despite the statistical difference between them for the attributes color and taste, since all evaluated attributes obtained scores above 5.0 (equivalent to the hedonic term 5 = "not liked/nor disliked") (Bárcenas and Rosell, 2006). 
Table 8. Mean values of the sensory acceptance and purchase intention tests, conducted with cookies made using refined wheat flour and whole wheat flour

\begin{tabular}{lcc}
\hline \multirow{2}{*}{ Attributes } & \multicolumn{2}{c}{ Formulations } \\
\cline { 2 - 3 } & F1 & F2 \\
\hline Appearance & 7.07 & 6.56 \\
Color & $7.17 *$ & 6.60 \\
Aroma & 6.90 & 6.50 \\
Taste & $6.96 *$ & 6.21 \\
Texture & 5.87 & 6.60 \\
Overall assessment & 7.08 & 6.92 \\
Purchase Intention & 4.04 & 3.79 \\
\hline
\end{tabular}

F1 - cookies without addition of S. platensis, produced with refined wheat flour; F2 cookies without addition of $S$. platensis, produced with whole wheat flour; *Statistical difference at 0.05 probability level by the Student's t-test

The mean values of the sensory acceptance and purchase intention tests, conducted with cookies made using refined wheat flour and different contents of S. platensis, are shown in Table 9. 
Table 9. Mean values of the sensory acceptance and purchase intention tests, conducted with cookies made using refined wheat flour and different contents of S. platensis.

\begin{tabular}{lcccc}
\hline \multirow{2}{*}{ Attributes } & \multicolumn{4}{c}{ Formulations } \\
\cline { 2 - 5 } & F1 & F3 & F4 & F5 \\
\hline Appearance & $7.36 \mathrm{a}$ & $4.60 \mathrm{~b}$ & $4.33 \mathrm{~b}$ & $4.22 \mathrm{~b}$ \\
Color & $7.40 \mathrm{a}$ & $4.66 \mathrm{~b}$ & $4.13 \mathrm{~b}$ & $3.96 \mathrm{~b}$ \\
Aroma & $6.87 \mathrm{a}$ & $5.98 \mathrm{~b}$ & $5.46 \mathrm{bc}$ & $5.06 \mathrm{c}$ \\
Taste & $6.73 \mathrm{a}$ & $5.89 \mathrm{ab}$ & $5.46 \mathrm{~b}$ & $5.40 \mathrm{~b}$ \\
Texture & $5.71 \mathrm{a}$ & $6.40 \mathrm{a}$ & $5.73 \mathrm{a}$ & $6.22 \mathrm{a}$ \\
Overall assessment & $6.89 \mathrm{a}$ & $5.95 \mathrm{~b}$ & $5.44 \mathrm{~b}$ & $5.28 \mathrm{~b}$ \\
Purchase Intention & $3.91 \mathrm{a}$ & $3.11 \mathrm{~b}$ & $2.76 \mathrm{~b}$ & $2.66 \mathrm{~b}$ \\
\hline
\end{tabular}

F1 - cookies without addition of S. platensis, produced with refined wheat flour; F2 cookies without addition of $S$. platensis, produced with whole wheat flour; F3 - cookies with $5 \%$ of S. platensis; F4 - cookies with $10 \%$ of S. platensis; F5 - cookies with $15 \%$ of $S$. platensis; Means followed by different letters in the same row differ by Tukey test $(\mathrm{P}<$ $0.05)$.

Taste is a very relevant attribute in the selection of a food. The formulations F1 and F3 stood out with the highest scores and did not differ statistically $(\mathrm{p}>0.05)$, a very important information in the elaboration of a new food, since the formulation F3 can be considered as functional, for incorporating $5 \%$ of S. platensis in its content.

The distribution of scores, according to the preference order of the tasters in the sensory analysis of cookies made using refined wheat flour and with different contents of S. platensis, is presented in Table 10.

Table 10. Distribution of scores according to the overall preference order by the tasters $(n=55)$ in the sensory analysis of cookies elaborated with refined wheat flour and with different contents of $S$. platensis.

\begin{tabular}{cccccc}
\hline \multirow{2}{*}{ Formulations } & \multicolumn{4}{c}{ Number of Tasters per Order } & \multirow{2}{*}{ Sum of orders $^{* *}$} \\
\cline { 2 - 5 } & $\mathbf{1}$ & $\mathbf{2}$ & $\mathbf{3}$ & $\mathbf{4}$ & \\
\hline F1 & 08 & 11 & 05 & 31 & $169 \mathrm{a}$ \\
F3 & 10 & 12 & 22 & 11 & $144 \mathrm{ab}$ \\
F4 & 12 & 22 & 18 & 03 & $122 \mathrm{~b}$ \\
F5 & 25 & 10 & 10 & 10 & $115 \mathrm{~b}$ \\
\hline
\end{tabular}

F1 - cookies without addition of $S$. platensis, produced with refined wheat flour; F2 
- cookies without addition of S. platensis, produced with whole wheat flour; F3 cookies with $5 \%$ of S. platensis; F4 - cookie with $10 \%$ of S. platensis; F5 - cookies with $15 \%$ of $S$. platensis; $* 1=$ least preferred, $4=$ most preferred.** Sum of the orders of each sample $=\left(1 \times \mathrm{n}^{\mathrm{o}}\right.$ of tasters $)+\left(2 \times \mathrm{n}^{\mathrm{o}}\right.$ of tasters $)+\left(3 \times \mathrm{n}^{\circ}\right.$ of tasters $)+$ (4 $\mathrm{x} \mathrm{n}^{\circ}$ of tasters); a, b - superscript lowercase letters indicate significant differences between the cookies $(p<0.05)$ by Friedman test

According to the ranking test, a higher number of tasters classified the F1 cookie sample as the most preferred, along with the F3 sample (lowest $S$. platensis percentage), which did not differ statistically. On the other hand, the samples F4 and F5 (higher $S$. platensis percentage) were classified as least preferred.

Table 11 shows the distribution of scores, according to the overall preference order of the tasters $(n=55)$ in the sensory analysis of cookies made using whole wheat flour and cookies enriched with $S$. platensis. The preference of the tasters is the same between cookies formulated with whole wheat flour and cookies enriched with different contents of $S$. platensis.

Table 11. Percentage distribution according to the overall preference order by the tasters $(n=55)$ in the sensory analysis of cookies made using whole wheat flour and cookies enriched with different contents of $S$. platensis

\begin{tabular}{cccccc}
\hline \multirow{2}{*}{ Formulations } & \multicolumn{4}{c}{ Number of Tasters per Order* } & Sum of orders \\
\cline { 2 - 5 } & $\mathbf{1}$ & $\mathbf{2}$ & $\mathbf{3}$ & $\mathbf{4}$ & \\
\hline F2 & 1 & 2 & 3 & 4 & $152 \mathrm{a}$ \\
F3 & 13 & 06 & 09 & 25 & $122 \mathrm{a}$ \\
F4 & 15 & 16 & 13 & 09 & $137 \mathrm{a}$ \\
F5 & 12 & 10 & 19 & 12 & $119 \mathrm{a}$ \\
\hline
\end{tabular}

F1 - cookies without addition of $S$. platensis, produced with refined wheat flour; F2 - cookies without addition of S. platensis, produced with whole wheat flour; F3 cookies with $5 \%$ of $S$. platensis; F4 - cookie with $10 \%$ of S. platensis; F5 - cookies with $15 \%$ of $S$. platensis; $* 1=$ least preferred, $4=$ most preferred.** Sum of the orders of each sample $=\left(1 \times \mathrm{n}^{\mathrm{o}}\right.$ of tasters $)+\left(2 \mathrm{x} \mathrm{n}^{\mathrm{o}}\right.$ of tasters $)+\left(3 \mathrm{x} \mathrm{n}^{\mathrm{o}}\right.$ of tasters $)+$ (4 $\mathrm{x} \mathrm{n}^{\circ}$ of tasters); $\mathrm{a}, \mathrm{b}$ - superscript lowercase letters indicate significant differences between the cookies $(p<0.05)$ by Friedman test

\section{Conclusions}

In the cookies, the increase of $S$. platensis percentage led to increase in protein percentage, besides increments of minerals, in comparison to the cookies produced only with refined wheat flour. Cookies with $15 \%$ of $S$. platensis (F5) stood out regarding the percentages of protein and minerals, and were similar to the whole cookies with respect to the minerals; 
lipids and highest energetic value were found in the standard cookies; cookies mixed with 5\% of $S$. platensis and standard cookies were preferred with the same score, indicating a possible acceptance in the market.

\section{Acknowledgment}

The authors would like to thank CNPq (National Council for Scientific and Technological Development) for the support given to this research (Process Number - 483940/2012-7).

\section{References}

Alvarenga, R. R. et al. (2011). Energy values and chemical composition of Spirulina (Spirulina platensis) evaluated with broilers. Revista Brasileira de Zootecnia, 40, 992-996. https://doi.org/10.1590/S1516-35982011000500008

AOAC - ASSOCIATION OF OFFICIAL ANALYTICAL CHEMISTS. (1997). Official Methods of Analysis. Williams, S. 14. Ed. Arlington, p.1141.

Arnon, D. I. (1949). Copper enzymes in isolated chloroplasts. Polyphenoloxidase in Beta vulgaris. Plant Physiology, 24, 1-15. https://doi.org/10.1104/pp.24.1.1

Banji, D. et al. (2013). Investigation on the role of Spirulina platensis in ameliorating behavioural changes, thyroid dysfunction and oxidative stress in offspring of pregnant rats exposed to fluoride. Food chemistry, 140, 321-331.

https://doi.org/10.1016/j.foodchem.2013.02.076

Bárcenas, M. E., \& Rosell, C. M. (2006). Different approaches for improving the quality and extending the shelf life of the partially baked bread: low temperatures and HPMC addition. Journal of food engineering, 72, 92-99. https://doi.org/10.1016/j.jfoodeng.2004.11.027

Batool, R. et al. (2013). Effect of nigella sativa meal protein isolates supplementation on the physical and sensory characteristics of cookies during storage. Pakistan Journal of Nutrition, 12, 521-528. https://doi.org/10.3923/pjn.2013.521.528

Benassi, M. T., \& Antunes, A. J. A. (1998). Comparison of meta-phosphoric and oxalic acids as extractant solutions for the determination of vitamin $\mathrm{C}$ in selected vegetables. Arquivos de Biologia e Tecnologia, 31, 507-573.

Brasil (1998). Ministério da Saúde. Agência Nacional de Vigilância Sanitária. Portaria no 31, de 13 de janeiro de 1998. Aprova o Regulamento Técnico referente a Alimentos Adicionados de Nutrientes Essenciais. Diário Oficinal da República Federativa do Brasil. Brasília (DF).

Brasil (2001). Ministério da Saúde. Agência Nacional de Vigilância Sanitária. Resolução RDC $\mathrm{n}^{\circ}$ 12, de 02 de janeiro de 2001. Regulamento Técnico sobre padrões microbiológicos para alimentos. Diário Oficial da União. Brasília. Seção I (7-E), 45-53.

Brasil (2003). Ministério da Saúde. Agência Nacional de Vigilância Sanitária. Resolução RDC no 360 de 23 de dezembro de 2003. Regulamento Técnico sobre Rotulagem Nutricional de Alimentos Embalados. Diário Oficial da União. Brasília. 
Brasil (2005). Ministério da Saúde. Agência Nacional de Vigilância Sanitária. Resolução RDC $\mathrm{n}^{\circ} 269$, de 22 de setembro de 2005. Regulamento Técnico sobre a Ingestão diária recomendada (IDR) de proteína, vitaminas e minerais. Diário Oficial da União.

Chevallier, S. et al. (2002). Structural and chemical modifications of short dough during baking. Journal of Cereal Science, 35, 1-10. https://doi.org/10.1006/jcrs.2001.0388

Colla, L. M. et al. (2007). Production of biomass and nutraceutical compounds by spirulina platensis under different temperature and nitrogen regimes. Bioresource technology, 98, 1489-1493. https://doi.org/10.1016/j.biortech.2005.09.030

Donato, N. R. et al. (2010). Use of Spirulina platensis for recovering rats under protein restriction diet feeding. Revista do Instituto Adolfo Lutz, 69, 69-77.

Dotto, G. L. et al. (2013). Equilibrium and thermodynamics of azo dyes biosorption onto Spirulina platensis. Brazilian Journal of Chemical Engineering, 30, 13-21. https://doi.org/10.1590/S0104-66322013000100003

Faria, E. V. D., \& Yotsuyanagi, K. (2002). Técnicas de análise sensorial. In Técnicas de análise sensorial. 1a ed. Campinas. Ital/Lafise. p.116.

Fasolin, L. H. et al. (2007). Biscoitos produzidos com farinha de banana: avaliações química, física e sensorial. Ciência e Tecnologia de Alimentos, 27, 524-529.

https://doi.org/10.1590/S0101-20612007000300016

García-Casal, M. N. et al. (2009). Antioxidant capacity, polyphenol content and iron bioavailability from algae (Ulva sp., Sargassum sp. and Porphyra sp.) in human subjects. British journal of nutrition, 101, 79-85. https://doi.org/10.1017/S0007114508994757

Guilherme, F. F., \& Jokl, L. (2005). Emprego de fubá de melhor qualidade protéica em farinhas mistas para produção de biscoitos. Ciência e Tecnologia de Alimentos, 25, 63-71. https://doi.org/10.1590/S0101-20612005000100011

Hoffmann, S. A., \& Kruger, R. L. (2011). Elaboração, análise sensorial e físico-química de biscoito rico em ferro com farinha de pulmão bovino. Alimentos e Nutrição, 22, 577-583.

Kim, K. et al. (2013). Impact of light intensity, $\mathrm{CO}_{2}$ concentration and bubble size on growth and fatty acid composition of arthrospira (Spirulina) platensis KMMCC CY-007. Biomass and Bioenergy, 49, 181-187. https://doi.org/10.1016/j.biombioe.2012.12.021

Lacerda, D. B. C. et al. (2009). Qualidade de biscoitos elaborados com farelo de arroz extrusado em substituição à farinha de trigo e fécula de mandioca. Archivos Latinoamericanos de Nutrición, 59, 199-205.

Larosa, G. et al. (2009). Aspectos sensoriais, nutricionais e tecnológicos de biscoito doce contendo farinha de 'okara'. Alimentos e Nutrição, 17, 151-157.

Lemes, A. C. et al. (2012). Fresh pasta production enriched with Spirulina platensis biomass. Brazilian Archives of Biology and Technology, 55, 741-750.

https://doi.org/10.1590/S1516-89132012000500014 
Madkour, F. F., Kamil, A., \& Nasr, H. S. (2012). Production and nutritive value of Spirulina platensis in reduced cost media. The Egyptian Journal of Aquatic Research, 38, 51-57. https://doi.org/10.1016/j.ejar.2012.09.003

Marcilío, R. et al. (2005). Avaliação da farinha de amaranto na elaboração de biscoito sem glúten do tipo cookie. Brazilian Journal of Food Technology, 8, 175-181.

Mazokopakis, E. E. et al. (2008). Acute rhabdomyolysis caused by Spirulina (Arthrospira platensis). Phytomedicine, 15, 525-527. https://doi.org/10.1016/j.phymed.2008.03.003

Mazokopakis, E. E. et al. (2013). The hypolipidaemic effects of Spirulina (Arthrospira platensis) supplementation in a Cretan population: a prospective study. Journal of the Science of Food and Agriculture, 94, 432-443. https://doi.org/10.1002/jsfa.6261

Mazokopakis, E. E. et al. (2014). The hepatoprotective and hypolipidemic effects of Spirulina (Arthrospira platensis) supplementation in a Cretan population with non-alcoholic fatty liver disease: a prospective pilot study. Annals of gastroenterology, 27, 387-394.

Mishra, P., Singh, V. P., \& Prasad, S. M. (2014). Spirulina and its nutritional importance: a possible approach for development of functional food. Biochemistry \& Pharmacology, 3, 1-2. https://doi.org/10.4172/2167-0501.1000e171

Mohammed, M. K., \& Mohd, M. K. (2011). Production of carotenoids (antioxidants/colourant) in Spirulina platensis in response to indole acetic acid (IAA). Journal of Engineering Science and Technology, 3, 4973-4979.

Mohsen, S. M. et al. (2009). Effect of substitution of soy protein isolate on aroma volatiles, chemical composition and sensory quality of wheat cookies. Journal of food science \& technology, 44(9), 1705-1712. https://doi.org/10.1111/j.1365-2621.2009.01978.x

Morais, M. G. D., Miranda, M. Z. D., \& Costa, J. A. V. (2009). Biscoitos de chocolate enriquecidos com Spirulina platensis: características físico-químicas, sensoriais e digestibilidade. Alimentos e Nutrição, 17, 323-328.

Moreira, L. M. et al. (2013). Spirulina platensis biomass cultivated in southern Brazil as a source of essential minerals and other nutrients. African Journal of Food Science, 7, 451-455. https://doi.org/10.5897/AJFS2013.1082

Moura, C. C. et al. (2014). Biscoitos enriquecidos com farelo de linhaça marrom (Linum usitatissiumun L.): valor nutritivo e aceitabilidade. Demetra: Food, Nutrition \& Health/Alimentação, Nutrição \& Saúde, 9, 71-81.

https://doi.org/10.12957/demetra.2014.6899

Oliveira, E. G. et al. (2010). Optimisation of Spirulina platensis convective drying: evaluation of phycocyanin loss and lipid oxidation. Journal of Food Science \& Technology, 45(8), 1572-1578. https://doi.org/10.1111/j.1365-2621.2010.02299.x

Rodrigues, J. P. M., Caliari, M., \& Asquieri, E. R. (2011). Caracterização e análise sensorial de biscoitos de polvilho elaborados com diferentes níveis de farelo de mandioca. Ciência 
Rural, 41, 2196-2102. https://doi.org/10.1590/S0103-84782011001200025

Rosell, C. M., Rojas, J. A., \& De Barber, C. B. (2001). Influence of hydrocolloids on dough rheology and bread quality. Food Hydrocolloids, 15, 75-81.

https://doi.org/10.1016/S0268-005X(00)00054-0

Sassano, C. E. N. et al. (2010). Evaluation of the composition of continuously-cultivated Arthrospira (Spirulina platensis) using ammonium chloride as nitrogen source. Biomass and bioenergy, 34, 1732-1738. https://doi.org/10.1016/j.biombioe.2010.07.002

Simas, K. N. et al. (2009). Effect of king palm (Archontophoenix alexandrae) flour incorporation on physicochemical and textural characteristics of gluten-free cookies. Journal of Food Science \& Technology, 44, 531-538.

https://doi.org/10.1111/j.1365-2621.2008.01840.x

Tharwat, A. A., \& Alturki, S. M. (2014). Spirulina platensis production using date palm substances and low cost media in the climatic conditions of Saudi Arabia. Advances in Environmental Biology, 8, 2350-2357.

Vanderzant, C., \& Splittstoesser, D. F. (1992). Compendium of methods for the microbiological examination of foods. (3th ed.). Washington: APHA, p. 1219.

Vázquez-Velasco, M. et al. (2014). Liver oxidation and inflammation in $\mathrm{Fa} / \mathrm{Fa}$ rats fed glucomannan/Spirulina -surimi. Food chemistry, 159, 215-221.

https://doi.org/10.1016/j.foodchem.2014.03.015

Vieira, M. A. et al. (2008). Physicochemical and sensory characteristics of cookies containing residue from king palm (Archontophoenix alexandrae) processing. Journal of food science \& technology, 43, 1534-1540. https://doi.org/10.1111/j.1365-2621.2007.01568.x

Zepka, L. Q. et al. (2010). Nutritional evaluation of single-cell protein produced by Aphanothece microscopica Nägeli. Bioresource technology, 101, 7107-7111.

https://doi.org/10.1016/j.biortech.2010.04.001

\section{Copyright Disclaimer}

Copyright for this article is retained by the author(s), with first publication rights granted to the journal.

This is an open-access article distributed under the terms and conditions of the Creative Commons Attribution license (http://creativecommons.org/licenses/by/4.0/). 